\title{
DELIBERATING ON INTERSECTIONALITY: WOMEN'S CONFERENCES IN RECIFE
}

\author{
DELIBERANDO SOBRE A INTERSECCIONALIDADE: \\ AS CONFERÊNCIAS DAS MULHERES DE RECIFE
}

Marie-Hélène Sa Vilas Boas ${ }^{1}$

\begin{abstract}
Resumo
Em que condições a deliberação assegura ainclusão de grupos sociais marginalizados? Segundo a crítica feminista das teorias deliberativas, essas podem reproduzir as desigualdades políticas quando não levam em consideração as assimetrias de poder entre grupos sociais. Por esta razão, algumas autoras defendem o reconhecimento explícito das minorias nos dispositivos deliberativos. Este artigo tem por objetivo analisar a dinâmica da deliberação quando reúne um grupo tradicionalmente subrepresentado e caracterizado pela sua diversidade, ou seja as mulheres. Baseado no estudo das conferências das mulheres de Recife, mostra que a combinação entre a política do reconhecimento e a deliberação leva tanto à integração quanto à marginalização de algumas mulheres, dependendo dos recursos que elas têm para defender suas "perspectivas".
\end{abstract}

Palavras-chaves: Deliberação. Mulheres. Interseccionalidade. Brasil.

PhD, Political science, IEP d'Aix-en-Provence, University of French Guyana, Guiana

Francesa.msavilas@hotmail.com 


\begin{abstract}
Under what conditions can deliberation include marginalized social groups? Several feminist authors criticize deliberative theory for reproducing power relations between social groups. They defend the explicit recognition of marginalized social groups within deliberative devices. This article aims to analyze the dynamics of deliberation when it gathers a traditionally underrepresented group, women. Based on the study of women's conferences in Recife, it shows that the combination the politics of recognition and deliberation can lead both to the integration and marginalization of different actors within the group of women, depending on the resources they have available to voice their perspectives.
\end{abstract}

Keywords: Deliberation. Women. Intersectionality. Brazil.

\title{
INTRODUCTION
}

$\mathrm{U}$

Tnder what conditions can deliberation include marginalized social groups? Deliberative democracy has been theorized as an answer to the limits of representative democracy. Indeed, collective deliberation on common good should favor the inclusion of civil society and produce legitimate decisions (HABERMAS, 1997; RAWLS, 2001). However, according to feminist theorists, deliberative devices may reproduce social inequalities when they are based on the principle of rational argumentation (YOUNG, 1985) and the separation between the public and private spheres (PATEMAN, 2010). The ideal of consensus that sustains deliberative democracy may favor dominant groups who are used to public speaking and whose point of view has been previously legitimized. Deliberation can therefore reproduce the domination of some social groups, principally white, educated males, if it aims only aims to widen the actors of the decision process without taking into consideration their social characteristics. For that reason, Iris Marion Young argues that a democratic project should be based on the explicit recognition of marginalized social groups, such as women, black people or homosexuals, so that their experiences of oppression 
- she calls "perspectives"- are included in public debates (YOUNG, 2000).

But such a proposition is criticized by other authors, for whom it leads to the essentialization of social groups. Chantal Mouffe (1993, p. 86) underlines that in Young's position, "there are groups with their interests and identities already given and politics is not about the construction of new identities, but about finding ways to satisfy the demands of the various parts in a way acceptable to all." Although she defends a radical democratic project, Mouffe reminds us that social groups do not exist per se but result from a political construction. Therefore, the politics of recognition could impede a dialogue between different oppressed groups and the construction of common identities. A similar criticism is made by Celian McBride (2005), for whom it may prevent the possibility for an individual to define their self-identity.

These debates highlight a tension between the politics of recognition and deliberative objectives: When minorities are integrated in a deliberative device, is it possible for them to express heterogenous points of view? Is the recognition of a social group compatible with the expression of its internal diversity? When deliberation is combined with the recognition of a specific group, is it more inclusive than "universal" experiences?

To consider these questions, we will analyze a specific device, women's conferences in Recife. This experience is interesting because it aims to gather women together to define municipal gender policies. It is therefore based on a double ambition, on the one hand, the recognition of a social group and on the other, the deliberation around public action.

Although centered on a social category, the composition of this device is heterogeneous due to its rules but also to the intrinsic diversity of the social group called on to participate. Black, lesbian and 
popular female activists and academics have criticized the unifying conception of women that initially guided occidental feminist thinking, for being based on the experience of white heterosexual, middle class women (CRENSHAW, 1989; SKEGGS, 1997; WITTIG, 1992). In Brazil, the reflection around women's experiences of domination first focused on the relation between class and gender. The initial aim was to distinguish these two social relations and theorize the specificity of gender oppression. Such an orientation can be explained by the "specific trajectory" of the feminist movement in Brazil and the link between its members and leftist organizations, where gender issues were marginalized (SARTI, 1988). More recently, Brazilian militant and academic works on race, class, sexual orientation and gender intersection have deepened the understanding of the heterogeneity of women's experiences (CARNEIRO, 2003, MARIANO, 2005; SWAIN, 1999).

In women's conferences, the unity and diversity of women's experiences is a topic of permanent discussion and confrontation. We will therefore question under what conditions the differences between women are recognized in the device.

In this participatory institution, the perspectives that receive more attention and recognition are those defended by the activists who play a central role within the field of local women's movements. More precisely, the ability to defend a point of view depends on the detention of what Alinne Bonetti calls a "political articulation capital" (capital de articulação política). This capital is characterized by two elements: the detention of knowledge, acquired during an academic or a militant trajectory, and the access to a network of social organizations, which can be local, national or international (BONETTI, 2007a, p. 101). In women's conferences, the position that participants have outside the device, and more particularly within the women's movement, determines their capacity to voice gender issues inside the device. The 
unequal legitimacy of participants enables the visibilization of some social relations, in particular the interpenetration between gender and race or sexual discrimination. But it also marginalizes other perspectives, in particular those expressed by low class women. The device is therefore both a place of integration and marginalization of different actors and perspectives within the group of women.

This study is based on a seven month ethnographic study realized in Recife, during the 3rd women's conference of 2006. It is based on 32 interviews with participants and administrative actors, as well as on the observation of the assemblies. During the latter, a survey was administrated in order to determine the social properties of the participants.

After presenting the process of construction of the women's conferences and the heterogeneous conceptions that sustain them, the perspectives defended by the inhabitants of poor neighborhoods and feminist activists will be analyzed. In the third part, it will be demonstrated that due to the unequal resources possessed by participants, some perspectives get more recognition than others.

\section{I) The Institutional Device: a Frame for Deliberation}

Several authors have argued that the institutional device is not a neutral instrument but reveals the "project" pursued by its instigators. In this perspective, Evelina Dagnino distinguishes the "democratic-participatory" project, that aims to include marginalized groups in the decision making process, and the neoliberal one oriented toward policy efficiency (DAGNINO, 2007). This analysis permits the understanding of why participatory institutions are widespread throughout Brazil and the world, through the influence of very different types of actors. However, it is necessary not to see each project as coherent and unequivocal. As for public policies, 
participatory instruments can rely on contradictory or unclear aims (HASSENTEUFEL, 2011, p. 36-37). The study of women's conferences illustrates that participatory devices can be the synthesis of different, even conflicting, conceptions of participation. Indeed, they rely on a democratic-participatory project, by pursuing the ambition of including a marginalized social group through the importation of a feminist repertoire of collective action in the political field. However, its rules are also based on antagonistic conceptions of who should have more legitimacy to determine gender policies.

\section{A) Including women: the heritage of a repertoire of feminist collective action}

The creation of a women's conference is the result of a process that started during the 2000 electoral campaign. The winning coalition led by the Worker's party candidate, João Paulo, focused on the inclusion of the excluded through participative devices. Among the electoral coalition, party female activists united to define a gender policy program, which included the idea of creating a participatory institution in order to have a better representation of women in the policies process.

This idea was concretized after João Paulo's election, by the newly formed administration, i.e., the Women's Coordination. Composed of activists from the parties of the coalition ${ }^{2}$, this new administration established women's conferences ${ }^{3}$. The latter is defined in collaboration with local social movements which were part of the Worker's party "networks" (SA VILAS BOAS, 2005), such as the Pernambuco Women's federation (Federação das Mulheres de Pernambuco - FMPE), the Pernambuco Black movement (Articulação de negras e negros de Pernambuco) and women of the Unified Worker's

\footnotetext{
2 The six member of Women's coordination were former activist of the Workers' party (PT), the Brazilian Socialist Party (PSB) and the Comunist Party of Brazil (PcdoB).

3 We can also highlight that a women's assembly has been introduced in the participatory budgeting of Recife.
} 
Central (Central Única dos Trabalhadores - CUT). The activist profile of the device's instigators led to the importation of some aspects of the repertoire of collective action (TILLY, 1986).

First, women's conferences are defined as a women-only institution. More precisely, the rules stipulate that only women aged over 16 have the right to speak, vote and represent others. Therefore, men can assist in the debate but without intervening or being elected. In practice, no man participates in the debates. This criterion is an importation of feminist and black movement forms of collective action, according to which, to release the voice of the oppressed, specific spaces need to be created. The absence or silence of men should allow women to formulate proper revindications, without having to suffer their symbolic and physical domination. But such a rule also results from the analysis of gender relations in existing participatory devices, especially participatory budgeting. Even if women's presence is high during the first rounds of assemblies, they are underrepresented among the elected delegates (RIBEIRO, 2007). Therefore, women's conferences aim to permit women to play a representative role. The promotion of female delegates should diffuse the idea that they can also be spokespersons and that representation is not a male prerogative. Women's conferences are credited for promoting substantive representation, that is to say, to guarantee the expression of a social group in the policy making process, but also symbolic representation, in order to change the cultural meanings and processes associated with political participation (FRASER, 2005) as a member of the Women's Coordination explained to us:

[Within the local government] we were asked: 'men can participate can't they? We said no, men are in all the other institutions. In women's conferences, women are going to determine propositions that will change their lives, so nobody can do it better than them themselves. They have 
to be encouraged to take decisions that influence their lives. Men can attend the debates, but only as observers. But speaking and voting, it is only women [...]. It is so naturalized that only men can be representatives. When women see other women becoming delegates, they think that they could become one as well. But if they only see men they will never think that they can occupy this same place.

Second, the name given to the device -"women's conference" and its women-only rule traduces a conception of the way gender policies should be defined. To reach equality between men and women, the measures adopted should rest on the experience of the oppressed. Therefore, even within local government, representative administrators are female. Moreover, local public policies on gender are mainly perceived as women-oriented measures which should help them to get more autonomy or legitimacy.

Third, by calling on women to participate as and for women, the conferences contribute, through their existence, to creating the political subject they gather. The device is based on a feminist conception of gender relations, according to which women are a social group united by the same experience of oppression. But if such a unity justifies the existence of the device, the latter also aims to recognize that different perspectives exist among women. Participants are indeed given different positions in the device, according to their residential, activist or professional trajectory.

\section{B) The women's conference design: the union of conflicting positions}

The design of the conferences defines from what position female citizens are invited to intervene. During the first round of assemblies, three types of actors are differentiated. The first are the female inhabitants of poor neighborhoods. They are called to invest the territorial assemblies organized in the districts, which are the most 
numerous: in 2006, 14 territorial assemblies were realized. The second type refers to activists. Members of organizations that struggle for women's causes meet separately in the "organization's assembly". The third criterion is professional. It designs female public servants who also have a specific assembly.

The choice of these three types of participants is justified by different goals and reveals conflicting conceptions on who, within civil society, should be allowed to speak on behalf of women. The main debate concerns the division between territorial assemblies and the organizational one. It overlaps a division, commonly made in Latin American women's movements, between feminist organizations and grassroots associations. This differentiation has also been theorized by Maxine Molyneux in academic literature, who differentiates these two types of movements by the interests they defend. While feminist organizations are supposed to focus on interests derived from the analysis of women's subordination (strategic gender interest), women's popular movements should favor practical demands linked to an immediate perceived need and that do not entail strategic goals such as women's emancipation or gender equality (practical gender interests) (MOLYNEUX, 2000).

During the process of definition of the women's conference, the creation of territorial assemblies was defended by the members of the Women's Coordination. In early 2000, the head of this administration was a member of the left wing of the Worker's party, the socialist democracy (DS), who had also actuated in the World March of Women (MMM) in Pernambuco before being nominated as women's coordinator. She values the participation of women but with a focus on grassroots organizations and inhabitants, as she points out:

We wanted to diversify the agenda, to have very heterogeneous demands, to include grassroots women in the debate around public policies [...]. We saw it as an 
opportunity for the women's movement to include women that are usually not part of the debates... to influence other women with the movement's agenda. And we thought it would be positive, not only for public administration but also for the women's movement which would have this debate with women interested by the subject but not already engaged for women.

The inclusion of grassroots women pursues a double objective. The first one is to include various perspectives on women's causes. Even without being an activist, female inhabitants are supposed to experience gender inequalities. Therefore, the territorial assemblies rely on the valorization of female knowledge of everyday inequalities. In some way, it values "citizen knowledge" (SINTOMER, 2008) based on the individual experience of oppression and not on a particular type of expertise or skills.

The presence of grassroots women is also seen as a way to teach new ideas within the inhabitants and help create larger women's movements. Therefore, if inhabitants are invited to express their "perspectives" on women's issues, the device should also play the role of "school of feminism" for actors who are supposed not to be familiar with gender issues, whether they are engaged in women's collective action or not, as the supervisor of the participatory process in Women's Coordination highlights:

All of us [from the women's coordination] came from the feminist movement. And when you are part of the feminist movement, you think that women's grassroots movements, the mother clubs... well, you think that they don't have a feminist debate. But now that I am in the government, I view the situation differently. I think that these movements had a strategy that was to speak to the State as mothers to achieve rights and citizenship. It's a strategy that worked in the past. But we want to bring them somewhere else; 
we want them not to think about women as mothers but as citizens.

Although, in practice, many participants of the territorial assemblies are linked to a grassroots organization, it is noticeable that it is as residents of a territory that they are included in assemblies.

Such a position can be differentiated from the one given to the actors who invest in the "organization's assembly". The creation of a specific space for activists was defended by social organizations, in particular the FMPE. For this federation, participation should not only aim at including everyday knowledge on inequalities but also valuing the expertise of feminist organizations. While for Women's Coordination, participation is understood as the inclusion of a wide range of actors, feminist activists associate it to the expression of an agenda constructed collectively in social organizations and based on skilled knowledge. An opposition is therefore made between grassroots women, whose discourse is not necessarily seen as representative of women's causes, and the voice of social organizations, whose expertise and collective mode of functioning should give them a better understanding of women's interests. It is according to such an opposition that one activist of the FMPE, who participated in the definition of the device, explains the introduction of an organization's assembly:

The government wanted to create assemblies by district only. So we asked: How is the movement going to be represented? So we succeeded in creating an organization's assembly. Because if you want to strengthen this space [women's conference], it is not only a question of number. Many women don't perceive women's oppression. It's important to bring expertise in politics. We are not conflicting with women's popular organizations but what is important is to qualify politics. Because when Dona 
Maria, who represents nobody, speaks, is it democratic? Who is more representative? [...].

The final device therefore unites contradictory conceptions of participation, by valuing everyday experiences and expertise on gender issues at the same time. These two types of knowledge are also attributed to different actors, who are therefore assigned a different position within the device, the one being invited to be "trained" to feminism, and the other being invited to "qualify" the debates. Such a division has an influence on the internal dynamics of the conference and on the way women perceive their role within it.

\section{II) The Different Meanings of Speaking in the Name of Women}

If participants are called on to intervene as women and for women in the device, though with different positions, this requirement has different meanings depending on their trajectory and the social groups they refer to. In the territorial assemblies, women's issues are incorporated in the framework of "communities" needs, whereas in the organizations' assembly, intersection between gender, race and sexual identity is the focus of the debates. These different perspectives cannot be seen as a reproduction of the division between practical and strategic interests of women. It rather shows that depending on the political and social environment where the participants actuate, their conceptions of women's causes vary.

\section{A) Community demands as gender issues?}

In the territorial assemblies, participants mostly speak in the name of a category, "women from the communities". The notion of community refers to a territory, poor neighborhood, and the social group that composes it. It was initially used in the 1950's by the Catholic Church and social workers to design a group, territorially 
based and characterized by poor conditions of living, which ought to be constructed and united in order to overcome the socio-economical difficulties its members faced. From the late 1960's onwards, this category spread through two types of processes. First, the military regime institutionalized it as a policy category used to designate the beneficiaries of the social policies implemented in rural and urban poor areas. Second, within the Catholic Church, the notion of community started to become a category of collective action, through the multiplication of Brazilian Ecclesiastic Communities (CEBs) (SA VILAS BOAS, 2012).

In the late 1970 's, during the democratic transition, the category community acquired a contestatory meaning, with the emergence of new social actors struggling for urban improvement and the restoration of democracy (SADER, 1988). It was in this context that many women's popular organizations were created in Recife and other Brazilian cities, within the CEBs or as part of the urban popular movement (ALVAREZ, 1990). The focus of the women's popular movement on urban issues, reflected by demands for localized infrastructure or basic collective needs, has been analyzed as the expression of gender interest that does not entail a strategic goal of emancipation for women. But such an analysis is restrictive. First, because women's grassroot's activism is heterogeneous and can lead to a redefinition of women's positions within the family and the public sphere (CALDEIRA, 1987; BONETTI, $2007 \mathrm{~b}$ ) and second, because it is based on a unified conception of the path to be followed to reach emancipation, without taking into consideration the diversity of what being a woman means (SKEGGS, 1997).

The identification of "women from the communities" can be understood as a way for inhabitants to categorize their dual position in sex and class social relations. This category is, indeed, mobilized to justify three types of demands. 
The first and the most important one is oriented to the creation or improvement of public infrastructure in the neighborhood where they live or in all poor neighborhoods, such as the reduction in waiting times in health centers, the creation of new rooms in schools or the extension of public lighting. Some of these proposals are specifically oriented to women's issues, for example when they concern the creation of women's shelters, but others have a purely territorial focus. The latter are not disconnected from women's needs but, on the contrary, they can be perceived as the first step to conquer autonomy, as a member of a community association points out:

If I were living in the center of the city, I wouldn't need means of transportation, public lighting. But in the suburbs to have a stable economic life, a woman needs to make much more effort. So we have to make a proposition for the majority. Of course, culture is important but I prefer a pavement that will protect me from getting ill or from falling. It's necessary to understand the needs of everyone. If you already have that, you will not see that it's necessary. It may seem very basic. But it is what we need [...]. If there is no bus for you to leave your house, how are you going to get your independence? It is a gender question. Public lighting as well, because it can be very dangerous for a women to walk in the street at night.

The second type of demand is linked to the economic activity of some women, especially the members of associations in poor neighborhoods, organized around the production of hand made products, such as soap, food or clothes. In Recife, as in other Brazilian cities, many women's popular organizations are structured around this type of production, from which its members earn an income. The proposals aim at gaining support for their activities, such as training or access to microcredit. 
The third type of proposal is oriented toward the recognition of the intersection between gender and race oppression. However, it is interesting to notice that although participants of the assemblies are mainly black or metis women, this type of proposition is less frequent than those made on behalf of "women from the communities". This relative lower frequency of references to racial identity compared to the community identification reveals the lesser politicization of this social relation in the urban popular movement.

But participants not only speak to formulate new demands. They also deliberate on a set of propositions presented by the government that they can accept, reject or modify. In this case, their interventions mainly aim at qualifying which social group should be the main beneficiary of public intervention. Again, the category "women from the communities" is predominant.

Table 1 - Proposals made and modified during the territorial assemblies in 2006

\begin{tabular}{|c|c|c|c|c|}
\hline Proposals & $\begin{array}{l}\text { Modified } \\
\text { proposal }\end{array}$ & New proposal & Total & $\%$ \\
\hline $\begin{array}{l}\text { Addition of the expression " for associa- } \\
\text { tion of production " }\end{array}$ & 3 & & 3 & 12 \\
\hline $\begin{array}{l}\text { Addition of the expression « for women } \\
\text { from the communities » }\end{array}$ & 9 & & 9 & 36 \\
\hline $\begin{array}{l}\text { Proposal related to the recognition of } \\
\text { ethnicity }\end{array}$ & 2 & 1 & 3 & 12 \\
\hline $\begin{array}{l}\text { Proposal related to the creation/ exten- } \\
\text { sion of a public service in a specific neigh- } \\
\text { borhood. }\end{array}$ & & 2 & 2 & 8 \\
\hline $\begin{array}{l}\text { Proposal related to the extension of pub- } \\
\text { lic services }\end{array}$ & & 6 & 6 & 24 \\
\hline Others & 2 & & 2 & 8 \\
\hline Total & 16 & 9 & 25 & 100 \\
\hline
\end{tabular}

Source: Document made by the author from 10 of 16 assembly reports. Internal document of women's coordination.

In the territorial assemblies, women formulate proposals that enhance how the precariousness of their urban environment and 
their insertion in the labor market has an influence on their living condition as women or inhabitants. Such a frame is not only the result of perceived immediate needs. It is linked to the composition of the assemblies, which gather many members of women's or territorial associations that have constructed urban improvements and income generation as one the main issues of collective action.

\section{B) Making visible the invisible}

In the organizations' assembly, the debates follow a different path. The categories used to qualify the subject of gender policies and the types of propositions made are less focused on low class women. The participants rather speak on behalf of women as a united social group, but they also defend some actors or intersectional forms of oppression that need special attention due to their invisibility in the public sphere.

This assembly essentially gathers activists from local NGO's, women's organizations of left wing political parties and trade unions. Within these actors, the FMPE plays a central role, which traduces the importance of this federation at the local level. Composed of nearly sixty organizations and independent activists, the FMPE is one of the largest women's movements in the state of Pernambuco. Initially animated by radical feminist organizations, it has gradually united different branches of women's movements, such as NGO's specialized in health issues, organizations of young feminists, lesbians and also some community associations. Although it is characterized by different conceptions of feminism (OLIVEIRA, 2002), the symbolic and material influence of some organizations, such as the SOS Corpo, has an influence on the way gender relations are defined within it (BONETTI, 2007a). More precisely, women's oppression is perceived as the result of a patriarchal system where women's bodies are appropriated by men. The assignation to maternity and the control of women's sexuality 
is, in this perspective, understood as one of the principal expressions of male domination. Legal abortion is one of the main claims of the federation and it symbolizes the conception of gender relation valued by the most influential activists and groups within it. But in parallel with this unifying conception, the recognition of women's differences is also an important topic of debate within the organization, especially the interrelation between gender and race or sexual oppression. This federation also has a specific composition. Although heterogeneous, the central protagonists are professionalized activists who actuate in the NGO, integrated to the implementation of public policies.

The conception of gender relations favored by the federation and the profile of its members has an influence on the debates and the way they are framed.

First, activists proposals differ from those made in the territorial assemblies in their aim and/or their technicity. Three types of decisions can be distinguished. The first one aims at creating information campaigns on subjects linked to gender or gender and race/sexual oppression. The second one, more technical, results from the experience of policy implementation. The third one, much rarer, asks for the improvement of public services. These three types of propositions are also linked to some specific topics. Some subjects are the focus of special attention, in particular the "reproductive rights", an expression that refers to a set of claims that includes abortion, as well as domestic violence. The examples below are illustrative:

«Facilitate the modification of abortion law by supporting the national mobilization for abortion liberalization» (1st type).

«Promote preventive action on womenss violence, child work, homophobia, lesbophobia and racism» (1st type).

«Guarantee that all means of contraception are analyzed 
by the health ethics committee (2nd type)

«Guarantee that the "midwife kit" is given to midwifes» (2nd type).

«Increase the number of nurseries near schools» (3rd type $)^{4}$.

Second, unlike the territorial assemblies, the proposals aim less at qualifying the group that should be the center of public action than the social relation that should be taken into consideration within it. In this perspective, two social relations are most frequently mentioned: homosexual and racial relations, as the second proposal shows. We can underline that if intersectional relations are at the heart of the debates, they rarely include class issues, which are hardly mentioned during the organization's assembly. Nevertheless, it does not mean that social inequalities are not taken into consideration, but they are integrated into other social relations, especially racial claims. More precisely, black women are seen as the poorest women because of the historical construction of gender and race in Brazil, which has lead to the overrepresentation of black women among certain professional categories, such as domestic employees. But the intersectionality between class and gender is not considered for itself, because of the conception of oppression valued by feminist organizations, in particular the FMPE. Masculine domination is primarily thought of as the corporal appropriation of women by men, distinguished from another type of domination resulting from the productive structure.

In the organization's assembly, activists therefore favor a different conception of women's oppression compared to inhabitants. Less centered on the interrelation between class and gender, they rely on their expertise to formulate propositions and highlight social relations that are corporally embedded.

Relatorio Entidades, Internal document of women's coordination, S/D. 


\section{III) The Selection of Legitimate Identities}

The final assembly of women's conferences gathers the delegates elected during the first rounds of assemblies. It therefore brings together the inhabitants elected in the territorial assemblies, the organization assemblies and members of the local government. This phase of the women's conference is a moment of selection of the proposals that should orientate local gender policies. Within it, participants have a distinct weight in the deliberation, due to the unequal legitimacy they have in the women's activist field. This assembly reproduces in some way the praxis of the feminist field, where a hierarchy can be observed between women, depending on the activist resources they have.

\section{A) The reproduction of the women's movement hierarchy}

In her study of the FMPE, Alinne Bonetti shows that although this organization gathers heterogeneous women, some with high academic and economic capital and others with lower, it is characterized by a certain hierarchy between its members depending on the "political articulation capital" they hold. This type of capital is mainly retained by professionalized activists who actuate in some prestigious local NGO, whereas "community" women generally present a lack of this type of capital.

The unequal legitimacy that women have in the FMPE can be observed, on a larger scale, in the final assembly of women's conferences. In the latter, the spatial positioning of participants and the allocation of speaking time traduce a division between some professionalized activists, principally from the FMPE, and inhabitants elected in the territorial assemblies.

In 2006, the assembly took place in a school hall, where chairs had been placed in front of a pillar. Most of the inhabitants were 
seated, whereas a dozen feminist activists remained standing close to the microphone. The corollary of this spatial segmentation was that few participants took the floor during the final assembly. It is worth highlighting that due to the rules of the device, which is the adoption of propositions by consensus, speaking is necessary to have an influence on the issues of the debates. This method is supposed to facilitate the adoption of an acceptable position for all participants and, if consensus is not reached, the vote is used as a last resort. In practice, consensus favors those who take the floor, while silence is taken to mean agreement with the decision made (MOUCHARD, 2009).

The act of speaking or remaining silent is linked to the position the participants holds in the women's field and its corollary, the meaning they give to their participation in women's conferences. The activists who take the floor are those who also play a central role within the FMPE and therefore, have a high legitimacy in the local women's field. For them, participation means promoting women's interests by defending the agenda of their organization. Therefore, they define themselves as "representatives" of women's causes. Representation is understood in a substantive way, as the fact of "acting in the interest of the represented", as one professionalized activist of the ONG "Loucas das Pedras Lilas", part of the FMPE, explains:

From our point of view, representation, whether it is of community or civil servants, has to be done by a women who is really representative. Because in the communities, it is clear that women have problems. But they are not necessarily representative because they don't make any work within the community or outside it. Of course, women's conferences also exist for women to learn... but feminist organizations make the difference, because the women who represent these organizations have a mandate, whereas women from community organizations may or may not have [...]. For me it is different, it is different to have an organization that works in "articulation" with 
others, that negotiates on a larger scale... than having a discussion in a neighborhood, which is much more open, but different.

The substantive understanding of representation goes with the questioning of community actors' legitimacy to speak on behalf of women's interests. The low "political articulation capital" that inhabitants possess and the way they frame gender issues - that they link to territorial claims - give them less authority, at least in the eyes of some activists, to define gender policies.

This conception is contested by women of poor neighborhoods, who perceive themselves as representative of a majoritarian group within the conference but also within the local population. Representativeness is here understood in a descriptive way, as the fact of resembling those being represented and experiencing the difficulties of women in the neighborhood. It is because they "feel it in the skin" that they believe they represent other women. But even if they contest their lack of representativity, community women have not necessarily acquired some types of knowledge, such as the capacity to speak publicly while referring to a feminist frame, which would allow them to be recognized by the most legitimate activists. J., an inhabitant who started to participate in women's conferences in 2002 expresses a high feeling of exclusion when talking of her first experience of participation in a women's conference.

What I observed is that some women consider that they should be more listened to than others. At the beginning, I felt very excluded [...]. It felt bad because when I said something, they were going to say the same thing, but with their words and for them, it seemed to be better than what I said. It seemed to be better when it came from somebody who was from the feminist movement. So often, I stayed silent. 
In the final assembly of the women's conference, the division between some feminist activists that take the floor and the majority of community women who remain silent reflects the unequal resources they have to get involved in a debate around gender policies. These dynamics have an influence on the perspectives recognized during the deliberation.

\section{B) Deliberating on identities}

During the final assembly, poor neighborhood women do not participate much in the deliberation. However, this does not mean that the proposals they made during the first round of assemblies are totally marginalized. The latter are mostly adopted by the whole assembly. But their perspective remains secondary compared to others.

In this assembly, participants have the right to reject, adopt or modify the propositions made during the first round. But they cannot formulate new ones. The possibility of modifying the demands is an important tool to determine which social group, within women, should be considered a priority in public action. Therefore, the final conference is, to some extent, a place of definition of which "identity" or social relation should be recognized. We can underline that during the process of deliberation, some proposals are "universalized", in order to respond to the interests of all women. This is more particularly the case when the proposition is made for a specific neighborhood or for the "communities' women". In this case, a gender general interest is invoked, whether by feminist activists or by the representant of the Women's Secretary, to departicularize the proposition. For example, the proposition "Stimulate women's participation in the Health Council through the integration of the community women's network" ended up in "Stimulate the participation of women in the Health Council", because this formulation was considered more inclusive. 
On the contrary, others are modified in order to take into consideration some social groups considered as invisible and who need, for the same reason, recognition by public authorities. This is more particularly the case for black women and lesbians, whose visibility is defended by black and lesbian feminist activists, principally of the FMPE. The latter invoke the specific discrimination that the group they belong to suffers and that is ignored in the public sphere.

The logic of universalization and focalization is therefore used to make visible or, on the contrary, to make invisible, different "identities". The result is that the social groups or social relations that are most often mentioned are linked to gender and race or gender and sexual orientation, as can be seen in the table below.

Table 2 - Categories adopted during the deliberations of the women's conference final assembly

\begin{tabular}{|c|c|c|}
\hline Category used & $\begin{array}{c}\text { Frequency of } \\
\text { occurrence }\end{array}$ & $\mathbf{\%}$ \\
\hline Women/ gender & 17 & 16 \\
\hline Black women/ race-ethnicity & 27 & 25 \\
\hline Lesbian / Homophobia- lesbophobia & 13 & 12 \\
\hline Young and old women/ Age & 5 & 4 \\
\hline Unemployed women- working class women & 5 & 4 \\
\hline Communities & 3 & 2,5 \\
\hline Others (disabled, sex workers, female victims of violence) & 15 & 14 \\
\hline Without any precision & 35 & 33 \\
\hline
\end{tabular}

Source: Prefeitura Municipal de Recife, 3 a Conferência Municipal da Mulher. Propostas finais, Recife, 2006, Table realized by the author.

It is interesting to highlight that the notion of "community" is not often used in the proposition finally adopted. Such an absence can be understood as the result of the silence of the neighborhood's women, on the one hand, and on the other, of the strong discursive activity of some activists that have theorized intersectionality of race, sexuality and gender in feminist movements. Therefore, if the proposition adopted does not exclude the perspective of the inhabitants - the latter 
are generally adopted- they marginalize the category of identification used by low class women to voice their interest.

In the women's conference in Recife, the articulation between the politics of recognition and deliberation implies ambivalent impact. Because of the social category it proposes to gather and the diversity of its public, the women's conference follows an inclusive project. This ambition is strengthened by the use that the participants make of the device, which is to highlight the diversity of women's perspectives. But at the same time, inequalities are not totally neutralized and some participants have more influence than others in the deliberations. This dynamicis, first, the result of the rules of the device itself, which sanction the idea that inhabitants from popular neighborhoods and activists have different competences on women's issues. Second, it reveals preexisting hierarchies in the field of women's movements, which are imported in the device and that orientate the way participants perceive their own legitimacy to define gender policies. The consequence is that in women's conferences, although intersectional forms of oppression are at the heart of the debates, some social relations receive more recognition than others. More precisely, the identification category that poor inhabitants use to define their perspective is relatively marginalized as is the social relation it reveals, which articulates gender and class oppression. But in parallel, other social relations, traditionally not taken into consideration receive more recognition, such as the articulation between sex, race and sexual orientation.

These case studies permit us to question two elements that the feminist critics of deliberative theory do not take into consideration. The first one is linked to the autonomy of the device. Is it possible to consider the internal rules of a device without analyzing the social 
and political environment in which it is inserted? In the case of the women's conference in Recife, the internal functioning of the device cannot be understood without an analysis of its environment, and more precisely, the norms that organize women's movements.

The second is related to the actors that should be the object of recognition within deliberative devices. When an oppressed social group is promoted, who should speak on its behalf? Should activists be privileged or "ordinary" members of the group? How can consideration of the necessary heterogeneity of social groups in the debate be taken into account? Finally, how can the inequalities between the members of an oppressed group be thought about within deliberative theory?

\section{BibLIOGRAPHY}

ALVAREZ, Sonia. Engendering democracy in Brazil: women's movements in transition politics. Princeton: Princeton University Press, 1990.

BONETTI, Alinne de Lima. Não basta ser mulher, tem de ter coragem: uma etnografia sobre gênero, poder, ativismo feminista popular e o campo político feminista de Recife-PE. 2007. Tese (Doutorado em Sociologia) - Universidade Estadual de Campinas, Campinas, 2007a.

BONETTI, Alinne de Lima. Para além da maternidade militante: mulheres de base e os ativismos. Cadernos do LEPAARQ, Pelotas, v. 4, n. 7-8, p. 81-102, dez. 2007b.

CALDEIRA, Teresa Pires do Rio. Mujeres, cotidiano e política. In: JELIN, Elisabeth (Org.). Participación, cuidadanía e identidad: las mujeres en los movimientos sociales latino-americanos. Genève: UNSRID, 1987. p. 75-128.

CARNEIRO, Sueli. Mulheres em movimento. Estudos Avançados, São Paulo, v. 17, n. 49, p. 117-132, 2003.

CRENSHAW, Kimberlé. Demarginalizing the intersection of race and sex: a black feminist critique of antidiscrimination doctrine, feminist theory and antiracist politics. Hein Online, Chicago, p. 139-167, 1989.

DAGNINO, Evelina. Participation, citizenship and democracy. Perverse confluence and displacement of meanings. In: NEVEU, Catherine (Org.). Cultures et pratiques participatives: perspectives comparées. Paris: L'Harmattan, 2007. p. 353-370. 
FRASER, Nancy. Mapping the feminist imagination: from redistribution to recognition to representation. Constellations, Oxford, v. 12, n. 3, p. 295-307, 2005.

HABERMAS, Jürgen. Droit et démocratie: entre faits et normes. Paris: Gallimard, 1997.

HASSENTEUFEL, Patrick. Sociologie politique de l'action publique. Paris: Armand Colin, 2011.

MARIANO, Silvana. O sujeito do feminismo e o pós-estruturalismo. Estudos Feministas, Rio de Janeiro, v. 13, n. 3, p. 483-505, 2005.

MCBRIDE, Cillian. Deliberative democracy and the politics of recognition. Political Studies, Surrey, v. 53, p. 497-515, 2005.

MOLYNEUX, Maxine. Mobilisation sans émancipation ? Participation des femmes, Etat et révolution au Nicaragua (extraits). In: BISILLAT, Jeanne; VERSCHUUR Christine (Org.). Le genre, un outil nécessaire. Genève, Paris: L'Harmattan, 2000. p. 123-131.

MOUCHARD, Daniel. Etre représenté: mobilisations d'«exclus» dans la France des années 1990. Paris: Economica, 2009.

MOUFFE, Chantal. The return of the political. Londres: Verso, 1993.

OLIVEIRA, Suzanne Marques Dantas de. O feminismo e suas diferenças: um estudo sobre o forum de mulheres de Pernambuco. 2002. Dissertação (Mestrado em Sociologia) - Universidade Federal do Pernambuco, Recife, 2002.

PATEMAN, Carole. Le contrat sexuel. Paris: Editions la découverte, IEC, 2010.

RAWLS, John. Libéralisme politique. Paris: PUF, 2001.

RIBEIRO, Uriella Coelho. As mulheres no orçamento participativo de Belo Horizonte. In: SEMINÁRIO NACIONAL MOVIMENTOS SOCIAIS, PARTICIPAÇÃO E DEMOCRACIA, 2., 2007, Florianópolis. Anais... Florianópolis, 2007. Disponível em: <http://gestaocompartilhada.pbh.gov.br/sites/ gestaocompartilhada.pbh.gov.br/files/biblioteca/arquivos/op_e_genero_em_bh_-_ uuriella_coelho_ribeiro_1.pdf >. Acesso em: 18 jul. 2015.

SA VILAS BOAS, Marie- Hélène. Du quartier à l'État: sociologie des publics des dispositifs participatifs brésiliens. Le cas des conférences municipales des femmes de Recife et de Londrina. 2012. Thesis (Doctor Political Science) - IEP d'Aix-enProvence, 2012.

SA VILAS BOAS, Marie-Hélène. L'institutionnalisation partisane: une étude du setorial femmes du PT à São Paulo. Cahiers des Amériques Latines, Paris, n. 48-49, p. 187-202, 2005. 
SADER, Eder. Quando novos personagens entrarem em cena: experiências, lutas e falas dos trabalhadores na grande São Paulo (1970-1980). São Paulo: Paz et Terra, 1988.

SARTI, Cynthia. Feminismo no Brasil: uma trajetória particular. Cadernos de Pesquisa, São Paulo, v. 64, p. 38-47, 1988.

SINTOMER, Yves. Du savoir d'usage au métier de citoyen? Raisons Politiques, Paris,v. 3, n. 31, p. 115-133, 2008.

SKEGGS, Beverley. Formations of class and gender: becoming respectable. London: Sage, 1997.

SWAIN, Tania. Feminismo e lesbianismo: a identidade em questão. CadernosPagu, Campinas, v. 12, p. 121-139, 1999.

TILLY, Charles. La France conteste de 1600 à nos jours. Paris: Fayard, 1986.

WITTIG, Monique. La pensée straight. Paris: Balland, 1982.

YOUNG, Iris Marion. Impartiality and the Civic Public : Some Implications of Feminist Critiques of Moral and Political Theory. PRAXIS International, Oxford, n. 3, p. 381-401, 1985.

YOUNG, Iris Marion. Inclusion and democracy. Oxford: Oxford Universiy Press, 2000. 